This article is licensed under the Creative Commons Attribution-NonCommercial 4.0 International License (CC BY-NC) (http://www.karger.com/Services/OpenAccessLicense). Usage and distribution for commercial purposes requires written permission.

\title{
Bilateral Syphilitic Optic Neuropathy with Secondary Autoimmune Optic Neuropathy and Poor Visual Outcome
}

\author{
Tanya Kowalski $^{\mathrm{a}}$ Dujon Fuzzard ${ }^{\mathrm{a}}$ Isla Williams ${ }^{\mathrm{b}, \mathrm{c}}$ Jonathan Darby ${ }^{\mathrm{c}}$ \\ Heather Gwen Mack ${ }^{d}$ \\ aRoyal Victorian Eye and Ear Hospital, East Melbourne, VIC, Australia; ${ }^{b}$ Monash University, \\ Alfred Hospital, Prahran, Melbourne, VIC, Australia; 'St Vincent's Hospital, \\ Fitzroy, VIC, Australia; ${ }^{d}$ Melbourne Medical School, University of Melbourne, \\ Parkville, VIC, Australia
}

\section{Keywords}

Syphilis · Treponema pallidum · Optic neuropathy · Neurosyphilis · Autoimmune optic neuropathy

\begin{abstract}
We describe the case of a 65 -year-old man who suffered progressive visual loss despite appropriate treatment of ocular syphilis. Our patient initially presented with a unilateral 6 th nerve palsy and associated double vision, which self-resolved over 6 months. His ophthalmic examination was otherwise normal. 12 months after the initial complaint, he represented with dyschromatopsia, reduced visual acuity, tonic pupils, and optic nerve atrophy. He tested positive for syphilis and was admitted for treatment of neurosyphilis with high-dose benzylpenicillin. Despite treatment, at a 4-month review his visual acuity remained poor and progression of optic nerve atrophy was noted alongside the development of bilateral central scotomas. Further testing was congruent with a diagnosis of autoimmune optic retinopathy. We propose
\end{abstract}




\section{Case Reports in Ophthalmology}

Case Rep Ophthalmol 2019;10:81-88

DOI: 10.1159/000496142

(c) 2019 The Author(s). Published by S. Karger AG, Basel www.karger.com/cop

Kowalski et al.: Bilateral Syphilitic Optic Neuropathy with Poor Visual Outcome

this to be secondary to his syphilitic infection. Syphilis is known as the "great mimicker," and despite being quite treatable, this case highlights ongoing complexity in the diagnosis and management of syphilis, unfortunately with a poor visual outcome.

(C) 2019 The Author(s)

Published by S. Karger AG, Basel

\section{Background}

The worldwide incidence of syphilis is increasing and is now approximately 8.7/100,000 population in North America. It is most frequently seen among men who have sex with men, with human immunodeficiency virus (HIV) co-infection often present. There has been a corresponding increase in reported ophthalmic manifestations of syphilis including keratitis, anterior and posterior segment inflammation, syphilitic optic neuropathy (SON), and neurosyphilis.

SON occurs in secondary and tertiary syphilis. Optic disc swelling may or may not be present [1], and neuroretinitis [2], perineuritis [3], and a chiasmal syndrome [4] can occur. Rarely, the optic nerve may be damaged by a gumma (non-specific granulomatous lesion) in tertiary syphilis [5]. Untreated SON results in blindness [6]. SON responds well to appropriate antibiotic treatment $[7,8]$. Oral prednisolone and sub-Tenon triamcinolone acetonide ( $40 \mathrm{mg}$ ) have been reported as adjunctive treatments $[9,10]$. The prognosis is poorer when treatment is commenced at advanced stages [11]. We report a case of SON with poor visual outcome despite early and appropriate treatment and discuss the possible mechanism of his visual loss.

\section{Case Report}

A 65-year-old Caucasian male presented with painless horizontal diplopia on left gaze. His past history included coronary artery stents, hypercholesterolaemia, and he was an exsmoker of 20 cigarettes/day. He denied intravenous drug use and having sex with men. His daily medications included amlodipine, valsartan, clopidogrel, and rosuvastatin. He had an ophthalmic history of left herpes simplex keratitis. Best corrected visual acuity was 6/9 (right) and 6/24 (left). The right cornea appeared normal; the left had stromal scarring without neovascularisation. Lenses, pupils, optic discs, and vitreoretinal examination were normal. He had left esotropia and left lateral rectus underactivity, with right gaze-evoked nystagmus. HardyRand-Rittler colour plates tested all plates correct bilaterally. Automated visual field testing (Humphrey, Zeiss, Oberkochen, Germany) was full in both eyes. Full blood examination, CRP, ESR, fasting lipids, and renal function were normal. MRI of the brain showed minor bilateral pontine ischaemic changes. He was not tested for syphilis. He was diagnosed with microvascular left 6th nerve palsy. Diplopia resolved spontaneously over the next 3 months and his 6th nerve palsy remained detectable for 6 months before fully resolving.

He represented 6 months later with 8 weeks of painless "smeared vision" with yellow, red and orange colours seen vividly in both eyes. On further questioning, he reported previous treatment for gonorrhoea, presence of a primary chancre 12 months earlier, and having had sexual intercourse with a same-sex partner for 2 years. Visual acuities were $6 / 12$ (right) and 


\section{Case Reports in Ophthalmology}

Case Rep Ophthalmol 2019;10:81-88

DOI: $10.1159 / 000496142$

(c) 2019 The Author(s). Published by S. Karger AG, Basel www.karger.com/cop

Kowalski et al.: Bilateral Syphilitic Optic Neuropathy with Poor Visual Outcome

left 6/30 (left) (vision summarised in Table 1). Anterior segment examination was unchanged. Both pupils were dilated with no constriction in response to light, accommodative targets or $0.1 \%$ topical pilocarpine. Optic discs had developed mild temporal pallor (Fig. 1). Vitreoretinal examination remained normal. Motility testing was full. Automated field testing suggested a right superior defect (Fig. 1), although reliability indices were low. Optical coherence tomography scan of the retinal nerve fibre layer and ganglion cell layer demonstrated thinning in both eyes. MRI of the brain was unchanged. Serum treponemal antibodies and Treponema pallidum particle agglutination were reactive, with rapid plasma reagin reactive titre of 1,280. Further testing is summarised in Table 2. He did not have a lumbar puncture at this time. He was diagnosed with neurosyphilis and admitted to hospital. He reported allergy (rash) to penicillin and was treated by penicillin desensitisation followed by high-dose intravenous (IV) benzylpenicillin (1.8 g 4-hourly) for 16 days. He received $50 \mathrm{mg}$ oral prednisolone for 3 days for Jarisch-Herxheimer reaction prophylaxis. Despite antibiotic treatment, serial examination showed the vision loss progressed to $6 / 60$ in both eyes by June 2014 (Table 1 ).

On review in July 2014, 4 months after diagnosis and antibiotic treatment, visual loss had progressed further to $2 / 60$ (right) and 3/60 (left), optic nerve pallor had increased, and a central scotoma had developed in both eyes. Lumbar puncture showed CSF weakly reactive to T. pallidum antibodies (EIA, fluorescent) and T. pallidum particle agglutination. Skin biopsy showed non-specific IgE, IgM and C3 immunofluorescence in the basement membrane and dermis. He was diagnosed with autoimmune optic neuropathy, re-admitted to hospital and treated with a second course of IV benzylpenicillin after repeat desensitisation, together with IV ceftriaxone $2 \mathrm{~g}$ daily given his earlier lack of response to penicillin, along with a 3-day course of IV methylprednisolone $1 \mathrm{~g}$ daily. He commenced immunosuppression and was discharged taking a tapering course of oral prednisolone, initially $75 \mathrm{mg}$ daily, oral doxycycline $100 \mathrm{mg}$ twice daily for 28 days and azathioprine $75 \mathrm{mg}$ daily, and 1 month later given a 3-day course of IV immunoglobulin (Octagam 5\% $45 \mathrm{~g}$ daily).

When last reviewed, there had been no response to sustained immunosuppression. Visual acuity was $3 / 60$ bilaterally and optic discs were atrophic. Pupils remained non-responsive to both light and accommodative targets. The patient withdrew from medical care and ceased all treatment.

Our patient has CSF-positive neurosyphilis with bilateral optic neuropathy and tonic pupils. Although he presented with only 8 weeks of visual symptoms, it is possible that the seemingly typical microvascular 6th nerve palsy 1 year earlier was early neurosyphilis. He denied risk factors and was not tested for syphilis at the time. Notwithstanding the uncertain onset of infection, his optic nerve function was normal at presentation with cranial nerve palsy, and he was treated appropriately within 8 weeks of first optic neuropathy symptoms with two courses of IV penicillin, IV high-dose steroids, and subsequent immunosuppression, but suffered progressive visual loss in the right followed by left eye with optic atrophy.

We hypothesise his progressive visual loss was due to the development of autoimmune optic neuropathy. This is supported by the relentless course despite appropriate treatment confirmed on serological response, skin biopsy positive for immunoreactant deposition, the most consistent marker of autoimmune optic neuropathy $[12,13]$, and the development of autoantibodies (cardiolipin IgG, anti-smooth muscle). Multiple reports have linked post-infectious immune dysregulation with the development of autoimmune disease targeting the nervous system and the optic nerve $[14,15]$. Syphilis is well known to induce autoantibody 
production. Although not all autoantibodies are necessarily pathogenic, this supports our case for autoimmune optic neuropathy complicating our patient's syphilitic optic neuropathy.

Ophthalmologists play an important role in diagnosing ocular and neurosyphilis. A high index of suspicion is necessary. Patients with syphilitic optic neuropathy need to be warned that visual loss may develop despite optimum therapy. Further research is needed to understand the mechanisms of visual loss in patients with syphilis.

\section{Statement of Ethics}

The authors have no ethical conflicts to disclose.

\section{Disclosure Statement}

The authors have no conflicts of interest to declare.

\section{References}

1 Graveson GS. Syphilitic optic neuritis. J Neurol Neurosurg Psychiatry. 1950 Aug;13(3):216-24.

2 Smith GT, Goldmeier D, Migdal C. Neurosyphilis with optic neuritis: an update. Postgrad Med J. 2006 Jan;82(963):36-9.

3 McLeish WM, Pulido JS, Holland S, Culbertson WW, Winward K. The ocular manifestations of syphilis in the human immunodeficiency virus type 1-infected host. Ophthalmology. 1990 Feb;97(2):196-203.

4 Hausman L. The surgical treatment of syphilitic optic atrophy due to chiasmal arachnoiditis. Am J Ophthalmol. 1941;24(2):119-32.

5 Rasool N, Stefater JA, Eliott D, Cestari DM. Isolated presumed optic nerve gumma, a rare presentation of neurosyphilis. Am J Ophthalmol Case Rep. 2017 Feb;6:7-10.

6 Segal P, Janiszewska-Geldner B, Leonowicz-Michniowska J. Results of penicillin therapy in syphilitic primary optic atrophy. Br J Vener Dis. 1960 Dec;36(4):257-60.

7 Balaskas K, Sergentanis TN, Giulieri S, Guex-Crosier Y. Analysis of significant factors influencing visual acuity in ocular syphilis. Br J Ophthalmol. 2011 Nov;95(11):1568-72.

8 Clement ME, Okeke NL, Hicks CB. Treatment of syphilis: a systematic review. JAMA. 2014 Nov;312(18):1905-17.

9 Prokosch V, Thanos S. Emerging syphilitic optic neuropathy: critical review and recommendations. Restor Neurol Neurosci. 2008;26(4-5):279-89.

10 Tomsak RL, Lystad LD, Katirji MB, Brassel TC. Rapid response of syphilitic optic neuritis to posterior subtenon's steroid injection. J Clin Neuroophthalmol. 1992 Mar;12(1):6-7.

11 Sacks JG, Osher RH, Elconin H. Progressive visual loss in syphilitic optic atrophy. J Clin Neuroophthalmol. 1983 Mar;3(1):5-8.

12 Bielory L, Kupersmith M, Warren F, Bystryn J, Frohman L. Skin biopsies in the evaluation of atypical optic neuropathies. Ocul Immunol Inflamm. 1993;1(3):231-42.

13 Riedel P, Wall M, Grey A, Cannon T, Folberg R, Thompson HS. Autoimmune optic neuropathy. Arch Ophthalmol. 1998 Aug;116(8):1121-4.

14 Pfausler B, Engelhardt K, Kampfl A, Spiss H, Taferner E, Schmutzhard E. Post-infectious central and peripheral nervous system diseases complicating Mycoplasma pneumoniae infection. Report of three cases and review of the literature. Eur J Neurol. 2002 Jan;9(1):93-6.

15 Snider LA, Swedo SE. Post-streptococcal autoimmune disorders of the central nervous system. Curr Opin Neurol. 2003 Jun;16(3):359-65. 


\section{Case Reports in Ophthalmology}

Case Rep Ophthalmol 2019;10:81-88

DOI: $10.1159 / 000496142$

(c) 2019 The Author(s). Published by S. Karger AG, Basel
www.karger.com/cop

Kowalski et al.: Bilateral Syphilitic Optic Neuropathy with Poor Visual Outcome
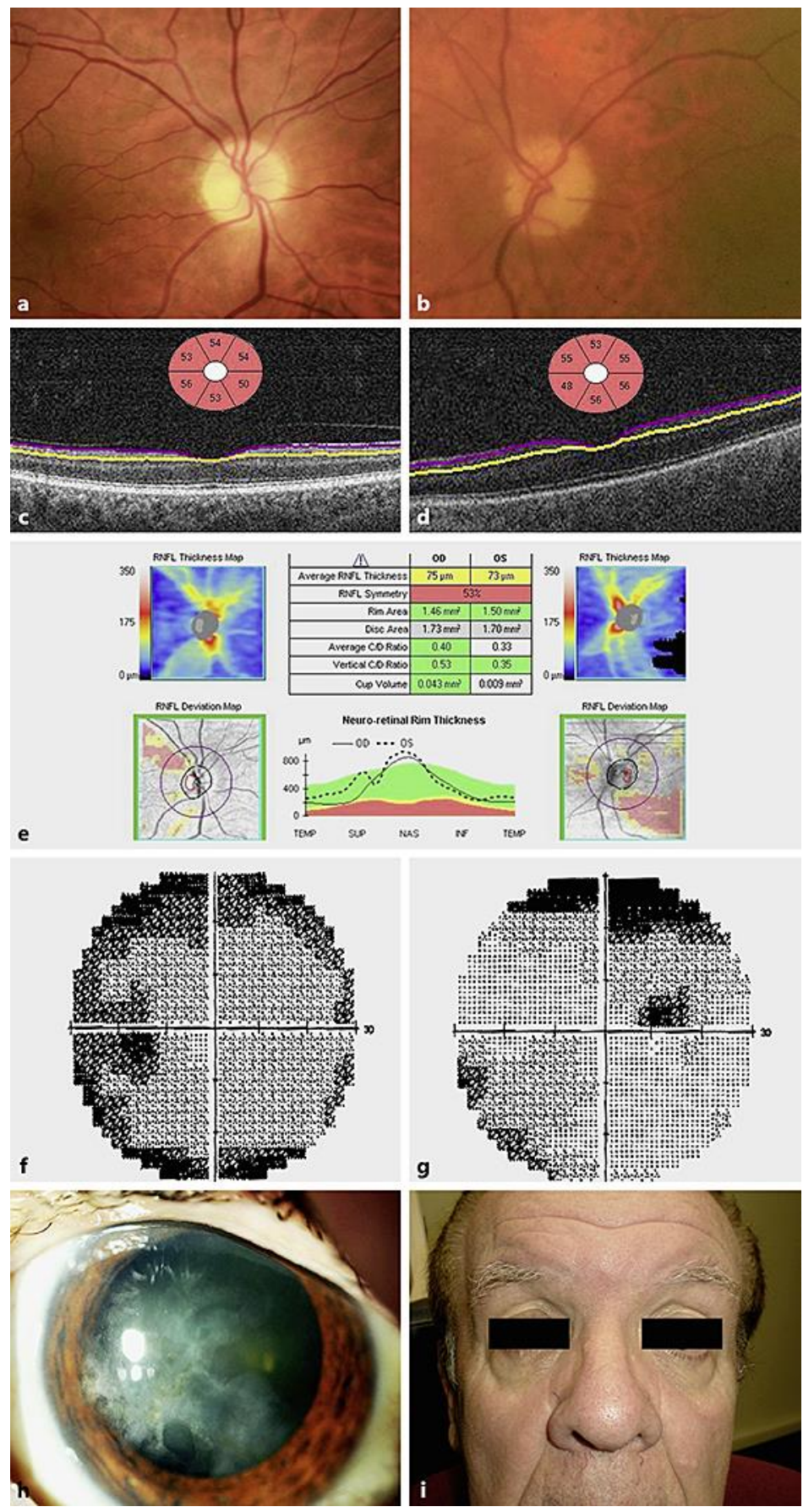

KARGER 
Fig. 1. A 65-year-old male with bilateral syphilitic optic neuropathy at presentation. Right (a) and left (b) colour fundus photographs showing mild optic disc pallor. Left view is blurred due to old herpetic keratitis. Ganglion cell layer scanning (Cirrus optical coherence tomographic scanning) of the right (c) and left eye (d). e Nerve fibre layer scanning of both eyes showing mild atrophy at presentation. Left (f) and right (g) automated visual field testing (Humphrey) showing a right superior defect. Reliability indices were poor. Colour photograph of the left cornea showing chronic herpes simplex keratitis scarring (h). Facial appearance showing lack of stigmata of congenital syphilis (i). 
Table 1. Chronological summary of visual acuity, visual fields and treatments received

\begin{tabular}{|c|c|c|c|}
\hline Date, event & Treatment & $\begin{array}{l}\text { Vision } \\
\text { (right, left }{ }^{1} \text { visual acuity } \\
\text { [Snellen], right, left Ishi- } \\
\text { hara plate testing) }\end{array}$ & Visual field \\
\hline $\begin{array}{l}2 / 2013 \text {, } \\
\text { presented with L 6th nerve } \\
\text { palsy }\end{array}$ & Nil & $\begin{array}{l}6 / 9,6 / 24 \\
\text { all correct, all correct }{ }^{2}\end{array}$ & Full both eyes \\
\hline $\begin{array}{l}3 / 2014, \\
\text { diagnosed with bilateral } \\
\text { syphilitic optic neuropathy }\end{array}$ & $\begin{array}{l}\text { Inpatient IV penicillin } 16 \text { days, } 50 \mathrm{mg} \\
\text { prednisolone oral/day for } 3 \text { days for } \\
\text { Jarisch-Herxheimer prophylaxis }\end{array}$ & $\begin{array}{l}6 / 18,6 / 36 \\
\text { TP only, } 8 / 14\end{array}$ & $\begin{array}{l}\text { Right superior } \\
\text { defect, left full }\end{array}$ \\
\hline $4 / 2014$ & & $\begin{array}{l}6 / 24,6 / 60 \\
\text { TP only, } 5 / 14\end{array}$ & \\
\hline $5 / 2014$ & & $\begin{array}{l}6 / 36,<6 / 60 \\
\text { fails TP, TP only }\end{array}$ & \\
\hline $6 / 2014$ & & $\begin{array}{l}6 / 60,6 / 60 \\
\text { fails TP, TP only }\end{array}$ & $\begin{array}{l}\text { Right central } \\
\text { scotoma, left full }\end{array}$ \\
\hline $\begin{array}{l}7 / 2014 \\
\text { second hospitalisation }\end{array}$ & $\begin{array}{l}\text { IV benzylpenicillin for } 14 \text { days. IV ceftriax- } \\
\text { one } 2 \mathrm{~g} \text { daily for } 16 \text { days, IV prednisolone } \\
1 \mathrm{~g} \text { for } 3 \text { days }\end{array}$ & $\begin{array}{l}2 / 60,6 / 60 \\
\text { fails TP, TP only }\end{array}$ & $\begin{array}{l}\text { Central scotoma } \\
\text { both eyes }\end{array}$ \\
\hline $\begin{array}{l}7 / 2014 \\
\text { post-discharge }\end{array}$ & $\begin{array}{l}\text { Prednisolone } 75 \mathrm{mg} \text { daily planned slow ta- } \\
\text { per, azathioprine } 75 \mathrm{mg} \text { daily, doxycycline } \\
100 \mathrm{mg} \text { b.i.d. for } 28 \text { days }\end{array}$ & & \\
\hline $\begin{array}{l}\text { 8/2014, } \\
\text { third hospitalisation }\end{array}$ & IV immunoglobulin $45 \mathrm{~g} /$ day for 3 days & $\begin{array}{l}2 / 60,3 / 60 \\
\text { fails TP, TP only }\end{array}$ & \\
\hline $9 / 2014$ & $\begin{array}{l}\text { Prednisolone } 75 \text { mg/day, azathioprine } 75 \\
\text { mg/day }\end{array}$ & $\begin{array}{l}3 / 60,3 / 60 \\
\text { fails TP, fails TP }\end{array}$ & \\
\hline $\begin{array}{l}12 / 2014 \text {, } \\
\text { patient withdrew from fur- } \\
\text { ther treatment }\end{array}$ & Nil & & \\
\hline
\end{tabular}

TP, test plate. ${ }^{1}$ Left visual acuity reduced at presentation by chronic herpes simplex keratitis. ${ }^{2}$ Hardy-Rand-Rittler testing at presentation with L 6th nerve palsy. 
Table 2. Investigations and results

\begin{tabular}{ll}
\hline Test & Result (normal range) \\
\hline Treponema antibody serum & Reactive \\
\hline Rapid plasma reagin serum & Reactive \\
& Titre 1,280 at diagnosis, 8 after treatment \\
\hline
\end{tabular}

Treponema pallidum particle aggluti- Reactive nation serum

CSF (after treatment intravenous pen-Clear, normal pressure, 5 lymphocytes, no malignant cells, oligocloicillin $\times 1)$

nal bands present, not matched with serum. Flow cytometry not performed.

T. pallidum antibody (EIA) reactive

T. pallidum FTA-Abs minimally reactive

T. pallidum particle agglutination minimally reactive

HIV Negative

Other sexually transmitted infections Gonorrhoea and chlamydia urine PCR negative Hepatitis B and C serum PCT negative

\begin{tabular}{ll}
\hline Quantiferon TB Gold & Negative \\
\hline Erythrocyte sedimentation rate & $39 \mathrm{~mm} / \mathrm{h}$ \\
\hline Tissue antibodies (serum) & $\begin{array}{l}\text { Anti-smooth muscle positive, titre 20 } \\
\text { Anti-mitochondrial negative }\end{array}$ \\
\hline Cardiolipin antibodies (serum) & $\begin{array}{l}\text { Cardiolipin IgG 25 }(<20) \\
\text { Cardiolipin IgM 3 }(<20)\end{array}$ \\
\hline Angiotensin converting enzyme & 24 U/L (20-70) \\
\hline Other auto-antibodies serum & $\begin{array}{l}\text { Anti-nuclear, anti-thrombin III, anti-nuclear cytoplasmic, extractable } \\
\text { nuclear antigens, anti-double stranded DNA, anti-neuronal, anti-reti- } \\
\text { nal, anti-NMO, lupus anti-coagulant all negative }\end{array}$ \\
\hline Serum electrophoresis & Normal, no oligoclonal bands \\
\hline Serum vitamin B $_{1}, B_{2}, B_{6}$ & Normal \\
\hline Serum immunoglobulins & Normal \\
\hline Serum complement & C3, C4 normal \\
\hline Urine protein electrophoresis & Normal \\
\hline
\end{tabular}

